Produto \& Produção, vol. 12, n. 2, p. 69 - 86, jun. 2011

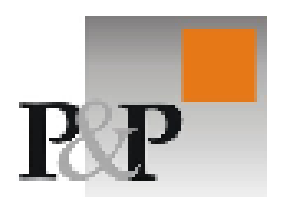

\title{
Banking operations using queuing theory and genetic algorithms
}

Recebido em 29/11/2010. Aceito em 23/02/2011.

\author{
Eder Oliveira Abensur \\ Professor UFABC \\ eder.abensur@ufabc.edu.br
}

Os caixas eletrônicos (ATM) são típicos equipamentos bancários presentes em agências, aeroportos e shoppings ao redor do mundo. O gerenciamento de uma rede proprietária de caixas eletrônicos representa uma parte significativa dos custos dos bancos de varejo brasileiros. Estes custos incluem, por exemplo, o valor dos equipamentos, depreciação, comunicação, aluguel, serviços técnicos, suporte operacional, sistema de monitoramento, energia e logística de suprimentos. Este estudo apresenta um modelo que determina a composição ideal de equipamentos de auto-atendimento em uma agência ao menor custo total sem comprometer a qualidade de atendimento prestado aos clientes. Apesar da importância do tema para o sistema financeiro, há uma escassez de trabalhos desta natureza. O modelo proposto foi desenvolvido integrando-se os conceitos da Teoria das Filas e de Algoritmos Genéticos. Ele foi testado sobre dados reais coletados de agências bancárias brasileiras. Os resultados demonstram que o método proposto é uma ferramenta gerencial promissora e flexível.

Palavras-chave: Caixas Eletrônicos, Teoria das Filas e Algoritmos Genéticos

Automatic Teller Machines (ATMs) are usual banking machines located within the branches, airports and malls around the world. The management of a network of ATMs represents a relevant part of the costs of retail banks. These include, for instance, purchase of equipment, depreciation, communication, rent of physical space, technical service, operational support, monitoring system, energy and supply logistics. This study presents a mathematical model that defines the mix of ATMs in a branch, trading-off lower costs and high quality customer service. Despite the relevance of the subject to Operations Management, there is a lack of work on ATM management. The proposed model was developed using the concepts of the Queuing Theory and Genetic Algorithms and was tested using one year of real data from Brazilian bank branches. Results indicate that the proposed model is a flexible and promising decision-making tool.

Keywords: Automatic Teller Machines (ATM), Queuing Theory and Genetic Algorithms 


\section{INTRODUÇÃO}

Despite the structural downsizing that has occurred over the last nine years in the Brazilian banking market due to the process of mergers and acquisitions the network of self-service equipment has grown significantly, as can be seen in Table 1. There has been a $659 \%$ increase in the number of ATMs and a $60 \%$ increase in the overall number of pieces of equipment, making the Brazilian market one of the largest in the world. This increase has been accompanied by an intensive use of Information Technology (IT) resources.

According to the Brazilian Banking Federation (FEBRABAN), 15.8 billion transactions are carried out at electronic cash-machines, or around $33 \%$ of all Brazilian banking transactions. The three largest Brazilian retail banks, individually, have more than 25,000 electronic cash machines geographically spread across a country of continental dimensions.

\begin{tabular}{|c|c|c|}
\hline Equipment & 2000 & 2009 \\
\hline ATMs - withdrawals and deposits & 15,639 & 42,245 \\
\hline $\begin{array}{l}\text { ATMs - adapted to physically disable } \\
\text { people }\end{array}$ & - & 76,498 \\
\hline Cash-dispenser & 47,618 & 27,011 \\
\hline Terminals for deposits & 15,700 & 13,804 \\
\hline $\begin{array}{l}\text { Terminals for statements and } \\
\text { balances }\end{array}$ & 22,260 & 1,392 \\
\hline $\begin{array}{l}\text { Check dispenser } \\
\text { Total }\end{array}$ & $\begin{array}{c}7,184 \\
108,401\end{array}$ & $\begin{array}{r}13,881 \\
173,439\end{array}$ \\
\hline
\end{tabular}

Brazilian retail banks have adopted self-service as an essential line for providing banking services making it a fundamental part of their corporate strategy. Despite the evolution of the use of alternative service channels, such as the Internet or Call Centers, the bank branch is still one of the main places for making payments in the Brazilian economy.

The management of ATMs, which is located within the branches, requires data about service demand, use by time of day and use by type of service, type of equipment, the time the equipment is occupied per type of service and the operating costs.

The diversity of banking services offered and the availability of different suppliers increase the complexity when it comes to defining the ideal mix (number, 
type) of ATMs, making it a complex decision-making activity. Management of these services comprises a series of decisions that are controlled (or not) by the banks, such as deciding the amount of equipment needed, the types of equipment and the selfservice costs, setting the time in line and considering restrictions imposed by current legislation.

In Brazil, the federal law called "Código de Defesa do Consumidor" describes the rights of Brazilian customers and determines general rules, but each municipality regulates details such as the time waiting in line for bank cashier service. In an attempt to protect the interests of users many municipalities changed the legislation in 2005 and established new time limits for standing in line waiting for bank branch cashier service. In São Paulo, the biggest Brazilian city the limits for standing in line are: (i) 15 minutes on normal days; (ii) 25 minutes on the eve of and day after public holidays, and (iii) 30 minutes on pay days (generally the $5^{\text {th }}$ working day of the month).

In the Brazilian financial market, the definition of the number of ATMs requires the balancing of two important areas: banking operations (physical infrastructure) and business area. Sometimes, the decision is more based on feeling rather than quantitative analysis. Break-even point analysis (LAMY, 1987) and simulation (ABENSUR et al., 2003) are some quantitative techniques applied to the problem under analysis.

The break-even point is a usual financial analysis which defines the number of transactions per equipment, balancing costs and income. The equation is defined by the division of fixed costs $(\mathrm{FC})$ by the unitary selling price $(\mathrm{Pu})$, or transactions fees in the analyzed situation, minus unitary variable cost (VCu), more explicity, BEP = FC / $(\mathrm{Pu}-\mathrm{VCu}$ ). The result (transactions) is compared to the estimated branch transactions to define the number of machines needed. BEP analysis presents many disadvantages such as: (i) many electronic transactions are free; (ii) the criterion ratio of fixed costs affects the results; (iii) it is an appropriate technique for a single-product company and (iv) it does not consider capacity and quality restrictions.

Despite the relevance of the financial system in the economy and the importance of the issue for bank operations there is a shortage of work of this type. The works of Abensur et al (2003), Castro (2009), Kouzelis (1987) and Murphy (1983) are exceptions. Other related articles deal with the general approach of multiple server models applied to service operations (ATKINSON et al., 2008, BERMAN; DREZNER, 2007, SYAM, 2008), but there is a lack of work on banking operations.

The information in this work was collected by means of a field survey carried out in a retail bank branch of one of the ten largest Brazilian financial institutions. It was possible to estimate the arrival flow of people who used the ATMs, stratified by day of the week and time.

The average time using the self-service equipment was obtained observing the individual time taken for processing the main transactions demanded by users (withdrawals, consultation, deposits, payments) over a period of one month. Results (mix of ATMs) were obtained applying two search methods: (i) Genetic Algorithms (GA), was applied to the non-linear model considering all the restrictions in an integrated way, including non-linear restrictions such as time in line, and (ii) Linear Programming (LP) was applied to a simplified model and the lowest cost composition was obtained. 
An application was developed based on an Excel spreadsheet and the search tool Evolver ${ }^{\circledR}$ with Genetic Algorithms for the complete non-linear model. The results of the simplified model were obtained using the Linear Programming's Solver. Figure 1 provides a simplified schematic of the problem environment of self service in branches presented in this paper.

The rest of this paper is structured as follows: Section 2 describes the theoretical basis, based on the concepts of the Queuing Theory and Genetic Algorithms. Section 3 gives an overview of the main data used in the model. Section 4 presents the proposed model. Section 5 presents the results and Section 6 gives the research conclusions.

\section{Objective:}

Optimize the combinantion of cost and average waiting time in queue

\section{Issues:}

a) Deciding the amount of equipment needed;

b) Deciding the types of equipment;

c) Defining self-service costs;

d) Time in line;

e) Restrictions imposed by current legislation.

\section{Tellers}

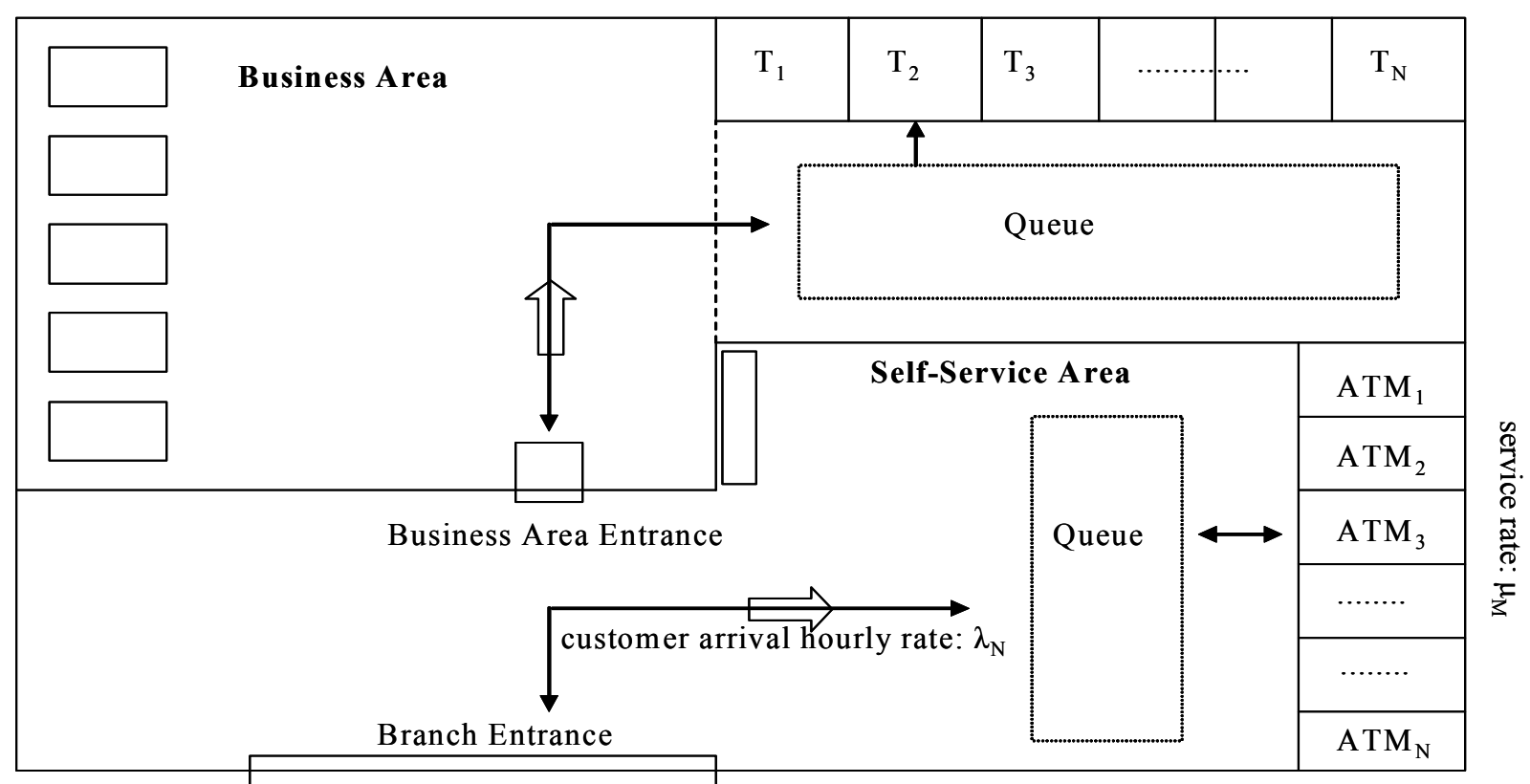

Figure 1 - Typical Brazilian branch 


\section{THEORETICAL BASIS}

\subsection{Queuing Theory}

A line is the consequence of a mismatch between the service capacity and user demand. The line plays an important role in the management of service operations because in many cases it is impractical to offer sufficient infrastructure to meet the demand of all users simultaneously. Time in line at ATMs has already been indicated as the biggest problem faced by users (THATCHER et al., 2005).

A line system is characterized by six factors: (i) the time distribution between arrivals (arrival process); (ii) distribution of the service time (time being attended to); (iii) number of those serving (channels or servers); (iv) discipline in serving the line (FIFO-First In, First Out; LIFO-Last In, Last Out, Priority); (v) capacity of the system, and (vi) size of the population or source from which the customers are generated (finite or infinite). An analysis of the factors relative to this problem leads to the the following characteristics:

I. Distribution of arrival times - users arrive in the bank branch randomly, with a probabilistic distribution that will be defined in Section 3.

II. Service time - the average time that users occupying self-service equipment was measured by timing them; this was divided into two parts: (i) individual time for processing the main transactions used by the users (withdrawals, consultations) and (ii) time wasted, due to users remaining in front of the equipment for personal reasons (checking their statement) or because of security demands (inserting the magnetic card twice, checking additional information, such as date of birth). The time occupying the ATM was presented as a probabilistic distribution that will be given in Section 3 .

III. Number of servers - the number of pieces of equipment by type of service is the decision variable whose optimal value is to be found as a result of the optimization.

IV. Discipline in serving the line - in Brazil, in general, lines are single and disciplined by order of arrival (FIFO-First In, First Out)

V. Capacity of the system - this is understood as being the maximum number of users possible on the premises of the self-service branch. This is a significant restriction because many of the places allocated to self-service were not planned for this purpose, but adapted to the existing physical space limitations. Therefore, the system presents a finite capacity, expressed by the number of users.

VI. Size of population - the source of daily users of a branch is plentiful and considered infinite for purposes of this study.

Of all the analytical queue models known the most suitable for this problem is the Multiple Server Model. According to the above information, the notation for this model is $(M / M / c):(F I F O / N / \infty)$, in other words, random time of arrival and attendance, $c$ servers, FIFO line service, capacity of the system limited to $N$ users and an infinite 
population. Figure 2 shows the main performance indicators of the $M / M / c$ queuing system, considering a nominal rate of arrival $\lambda$ and a service rate by piece of equipment $\mu$ with a rate of arrival divided by a service rate by piece of equipment $\rho=\lambda$ $/ \mu$. The parameters $p, L_{q}$ and $W_{q}$ represent, respectively, the probability of users in the system, the length of the queue and the average waiting time in the queue (HEIZER; RENDER, 1999, HILLIER; LIEBERMAN, 1988, TAHA, 2008).

$\lambda_{n}=\left\{\begin{array}{l}\lambda, 0 \leq n \leq N \\ 0, n>N\end{array}\right\}$
$\mu_{n}=\left\{\begin{array}{l}n \mu, 0 \leq n \leq c \\ c \mu, c \leq n \leq N\end{array}\right\}$
$p_{n}=\left\{\begin{array}{l}\frac{\rho^{n}}{n !} p_{0}, 0 \leq n \leq c \\ \frac{\rho^{n}}{c ! c^{n-c}} p_{0}, \mathrm{c} \leq n \leq N\end{array}\right\}$
$W_{q}=\frac{\text { (1) (rate of arrival) }}{\lambda}$
$W_{0}=\frac{L_{q}}{\left[\begin{array}{l}c-1 \\ \sum_{n=0} \frac{1}{n !}(\rho)^{n}\end{array}\right]+\frac{1}{c !}(\rho)^{n} \frac{c \mu}{c \mu-\lambda}} \quad$ para $c \mu>\lambda$ (4) (probability of $n$ users in the system)
$L_{q}=\frac{1}{(c-1) !(c \mu-\lambda)^{2}}=\frac{L_{q}}{\lambda}+\frac{1}{\mu}$
$\frac{\lambda \mu(\rho)^{c}}{c} p_{0}$

Figure 2 - Queuing equations for M/M/c model 


\subsection{Genetic Algorithms}

Heuristics are procedures for solving problems using an intuitive, generally rational approach, in which the structure of the problem can be interpreted and explored in such a way as to obtain a reasonable solution. The main characteristics of heuristic procedures are: (i) good performance; (ii) speed; (iii) simplicity, and (iv) no guarantee of an optimum solution.

Metaheuristics appeared on the scene in the 80s. They strengthen and revitalize heuristic techniques through search mechanisms inspired in models drawn from human daily life or nature. Among them are the Genetic Algorithms (GA). The concept of GA was originally put forward by Holland (1975). The foundation for the algorithm is based on the observation that a combination of sexual reproduction and natural selection allows nature to develop living species with a high degree of adaptation to the environment.

In GA the word 'chromosome' refers typically to a candidate solution to a problem, which is normally codified as a sequence of bits. Functionally, the generic algorithm uses the following operators:

a) Reproduction - the initial solution is formed from a sequence of bits that represent the characteristic of the product. The selection operator chooses a sub-set $m$ of size $M$ chromosomes from the population that will be able to reproduce; on average, the more adapted chromosomes produce more descendents than the less adapted. The size of the chromosome is normally maintained in successive generations.

b) Crossover - the crossover operator exchanges parts of chromosomes from specifically chosen positions to form new descendents.

c) Mutation - the mutation operator exchanges the values of some parts of the chromosome in a random way

The basic objective of genetic algorithms is to suggest solutions for the problem to be solved and to evolve them over time. This objective is achieved by allowing those solutions that are more adapted to the problem to have a greater chance of survival and as a result greater opportunity to generate descendent solutions that have a greater possibility of being adapted.

In carrying out their search process genetic algorithms present a series of advantages. The main one is that the search is conducted on a population of points instead of a single point, thereby increasing the method's exploratory capacity. GA use objective functions to compare results, a facilitating characteristic that is in contrast to other techniques that need additional resources, such as function differentiation. The basic approach is described below (BALAKRISHNAN; JACOB, 1996) and shown in Figure 3. 


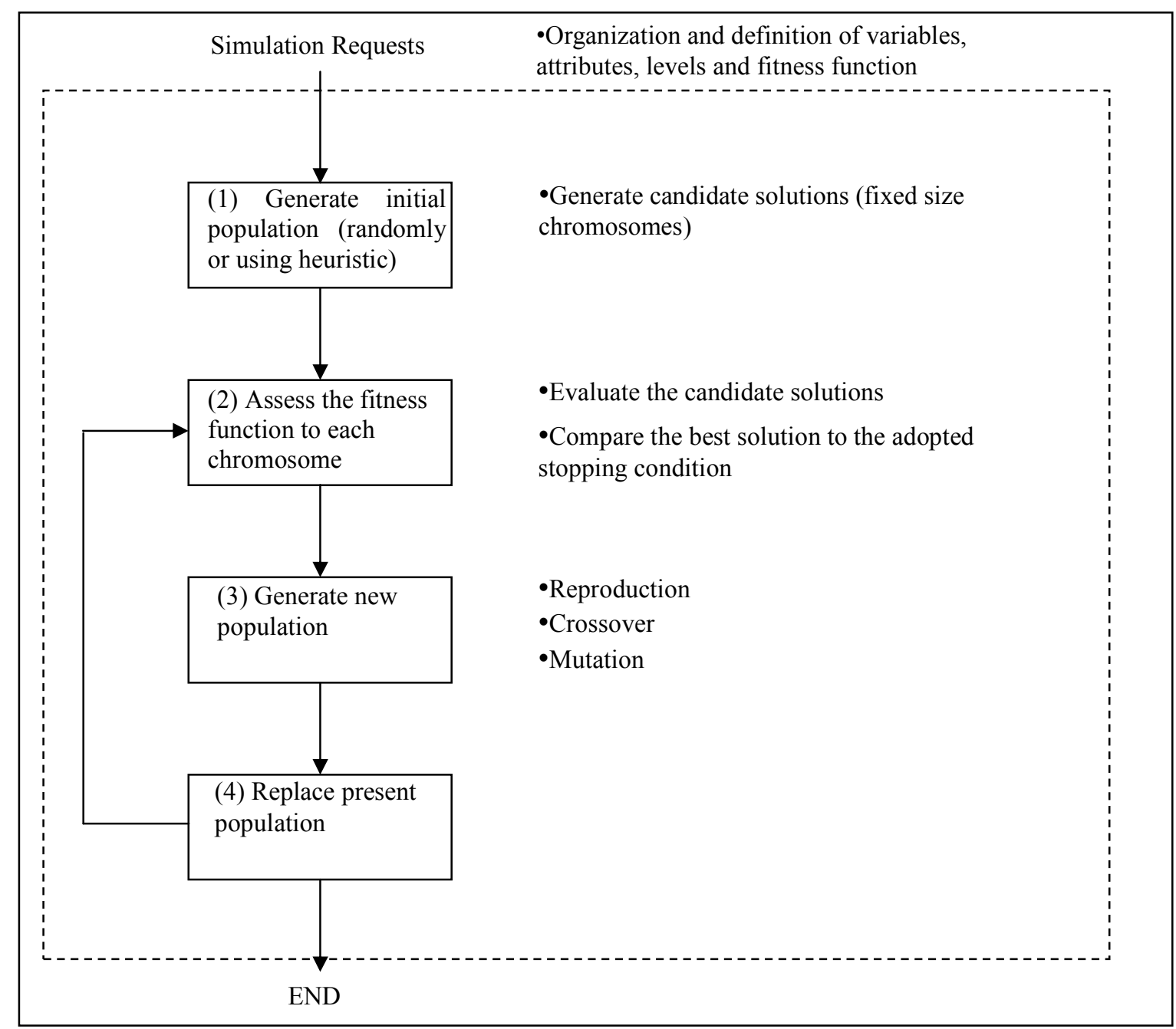

Figure 3 - Basic model of a genetic algorithm

Source: the author

\section{DATA COLLECTION}

\subsection{Occupancy Times}

Data was collected over a period of a month during banking hours in a retail branch of one of the ten largest Brazilian banks, using field measurements of equipments' occupancy time by customers in accordance with the type of service. These data served to estimate the average occupancy time by type of service. Due to the time limit imposed by the institution, it was not possible to achieve statistical error goals for all the transactions observed. In some cases, several months of collecting activity would be necessary to achieve classical levels of confidence such as $95 \%$ or $99 \%$. In order to assess and control, statistically, the observations done, the maximum statistical error was determined and is presented in Table 2. 
The branch was chosen because its customers are both diversified and representative of the Brazilian banking customer population. The greatest possible number of observations was collected within the preference limits of the population for these services. When collecting the data the influence of factors such as age, cultural level, gender and physical disability (sight, movement) in forming occupancy times was noticed. next:

The main criteria used when performing the measurements are summarized

a) measurement of occupancy times of the customer by type of transaction and by equipment without the help of bank employees;

b) times measured as from the time the equipment was occupied until it became idle;

c) time for customers to leave the line and reach the equipment was not considered;

d) measurement errors were calculated $90 \%$ confidence level by means of the Student distribution, for samples smallerr than 30 observations, and by a Normal distribution otherwise (LARSON; FARBER, 2004);

e) average times spent in line were measured.

Figure 4 and Table 2 show the composition of transactions carried out at the ATMs in the branch in accordance with the stratification obtained from the IT system and the occupancy times per piece of equipment and by type of service, respectively. Table 3 gives a summarized description of the transactions analyzed.

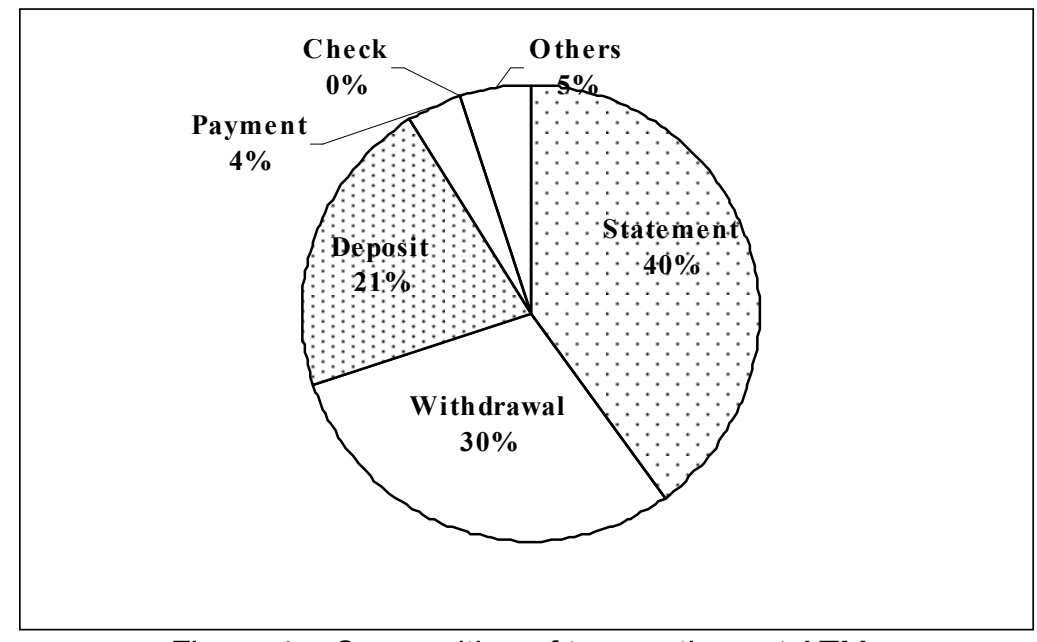

Figure 4 - Composition of transactions at ATMs 


\begin{tabular}{clccc}
\hline Machine & Transaction & Average (min) & Average (s) & Err \\
\hline $\mathrm{A}$ & Withdrawal & 0,59 & 35,40 & $6,7 \%$ \\
& On-screen statement & 0,61 & 36,60 & $8,3 \%$ \\
& Printed statement & 1,19 & 71,40 & $8,8 \%$ \\
& Deposit & 1,06 & 63,60 & $24,9 \%$ \\
& Payment & 2,16 & 129,60 & $29,0 \%$ \\
& Others & 1,53 & 91,80 & $20,4 \%$ \\
& & & & \\
& Beposit & 0,87 & 52,20 & $10,3 \%$ \\
& On-screen statement & - & - & - \\
& Printed statement & - & - & - \\
& Others & - & - & - \\
& & & & $11,5 \%$ \\
\hline
\end{tabular}

Table 2 - Occupancy times per piece of equipment and type of service Source: prepared by the author

\begin{tabular}{ll}
\hline Service & Description \\
\hline Withdrawal & Amount of money requested by means of electronic password \\
On-screen & Presentation of entries in the current account for periods of time \\
statement & that are pre-established by the equipment on-screen \\
Printed & Print-out of entries in the current account for periods of time that \\
statement & are pre-established by the equipment on-screen \\
Deposit & Deposit of amounts in money or checks using sealed envelopes \\
Payment & $\begin{array}{l}\text { Payment of non-overdue invoices using a barcode or manual } \\
\text { input }\end{array}$ \\
Check & Printing of up to 20 checks \\
Others & E.g.: Transfers, investments, etc \\
\hline & \multicolumn{1}{c}{ Table 3-Description of the services on offer } \\
& Source: prepared by the author
\end{tabular}

\subsection{Demand for Services}

The institution's IT system provided one year of data organized by the hour the transaction took place, which allowed determining the busiest time per type of service for the two branches that were considered as representatives of high and low demand for services. This data was used to determine maximum demand (peak demand). These demands were used to decide on the amount of equipment needed in the model.

Services present a seasonal demand throughout the month, with greater intensity in the first two weeks due to salary payments (generally on the $5^{\text {th }}$ working day), social security payments (throughout the first two weeks) and ordinary payments (generally up to the $10^{\text {th }}$ day of each month). On a daily basis, demand was more intense during the lunch period (midday to $2 \mathrm{PM}$ ), as expected. Figure 5 shows the hourly distribution of demand for services in a high demand branch. Maximum hourly 
demand per type of service for high and low demand branches is summarized in Table 4.

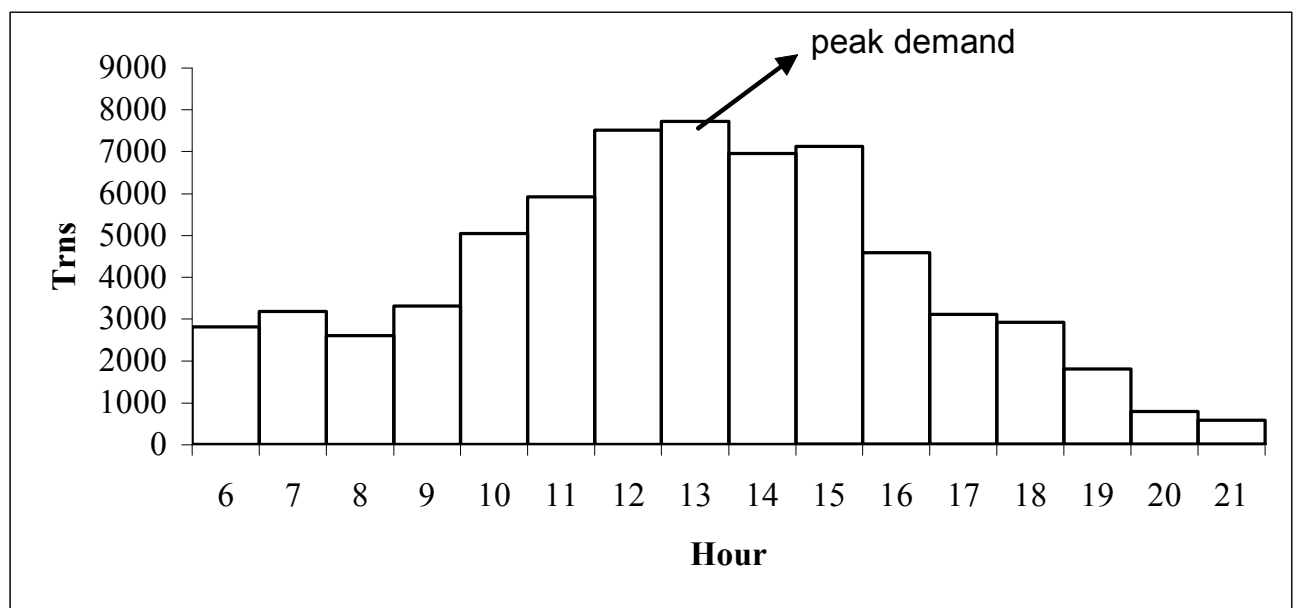

Figure 5 - Hourly histogram of service demand

\begin{tabular}{ccc}
\hline Transaction & High demand & Low demand \\
\hline Withdrawal & 37 & 24 \\
On-screen & 28 & 3 \\
consultation & & \\
Printed & 15 & 14 \\
consultation & & \\
Deposit & 30 & 5 \\
Payment & 6 & 3 \\
Check & 0 & 0 \\
Others & 7 & 3 \\
\hline
\end{tabular}

Table 4 - Maximum hourly demand

\subsection{Costs}

The costs identified were divided into fixed (relating to the equipment) and variable (relating to the volume of transactions). Among the main variable costs are: (i) unit costs of inputs, such as paper reels, toner, envelopes, forms and covers (check books) and (ii) data processing, related to the time the bank's mainframe CPU is occupied. The main fixed costs are: depreciation, investment amortization (purchase of equipment), communication (dedicated telephone lines), rent of physical space, technical service, operational support, monitoring system, energy and supply logistics. For reasons of confidentiality cost data have been omitted. 


\section{FORMULATION OF THE PROPOSED MODEL}

The objective of the model is to determine the composition of equipment that represents the lowest overall cost (fixed + variable) to the bank without compromising the service provided to customers. There are several equipment models (multifunctional or specialist) available for the same service that have different costs and productivity which increases the possible combinations. Time spent in line was used as the criterion of quality service provision.

Although there is no specific legislation for time in line at ATMs, the parameters for human cash points were used as a reference in the model simulations. The generic matrix representing the interaction between resources (equipment), services, demand and restrictions (capacity, line) is shown in Figure 6. The intersections of lines and columns represent costs and the time the service was occupied on the respective equipment. Simulations are carried out based on the peak demand obtained in Section 3. Figure 7 gives an example of the chromosome of the analyzed high demand problem using all machines. Attributes are related to machines and transactions while levels are related to the range of each attribute (Table 2).

To better illustrate the complexity of the problem, eleven attributes, each explored at the levels cited below, may lead to $2,93 \times 10^{15}$ $(6 \times 6 \times 3 \times 103 \times 99 \times 51 \times 58 \times 29 \times 40 \times 31 \times 25)$ candidate solutions. Moreover, in realistic and dynamic applications the number of possible solutions increases dramatically and it becomes unfeasible to obtain an optimal solution in a reasonable amount of time (BALAKRISHNAN; JACOB, 1996).

\begin{tabular}{|c|c|c|c|c|c|c|c|c|}
\hline RESOURCE & Withdrawal & $\begin{array}{c}\text { Printed } \\
\text { Statement }\end{array}$ & $\begin{array}{r}\text { SER } \\
\text { On-screen } \\
\text { Statement }\end{array}$ & $\begin{array}{l}\text { ICES } \\
\text { Deposit }\end{array}$ & Payment & Others & $\begin{array}{c}\text { RESTRI } \\
\text { Physical } \\
\text { capacity/time }\end{array}$ & $\begin{array}{l}\text { NS } \\
\text { Line }\end{array}$ \\
\hline ATM 1 & $\mathrm{c}_{11 /} \mathrm{t}_{11}$ & $\mathrm{c}_{12 /} \mathrm{t}_{12}$ & $\mathrm{c}_{13} \mathrm{t}_{13}$ & 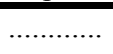 & …............ & $\mathrm{c}_{16 / 16} \mathrm{t}_{16}$ & $\mathrm{C} 1 / \mathrm{H} 1$ & \\
\hline & . & . & . & & & . & & time \\
\hline ATM 2 & . & . & . & & & . & $\mathrm{C} 2 / \mathrm{H} 2$ & \\
\hline ……....... & $\cdot$ & $\cdot$ & $\cdot$ & & & . & ……........ & \\
\hline ATM n & $\mathrm{c}_{\mathrm{n} 1 /} \mathrm{t}_{\mathrm{n} 1}$ & $\mathrm{c}_{\mathrm{n} 2} / \mathrm{t}_{\mathrm{n} 2}$ & $\mathrm{c}_{\mathrm{n} 3 /} \cdot \mathrm{t}_{\mathrm{n} 3}$ & ................ & ............. & $\mathrm{c}_{\mathrm{n} 6 / \mathrm{t}} \cdot \mathrm{t}_{\mathrm{n} 6}$ & $\mathrm{Cn} / \mathrm{H}_{\mathrm{n}}$ & \\
\hline & Ds & Dei & $\begin{array}{l}\text { Det } \\
\text { DEI }\end{array}$ & $\begin{array}{c}\text { Dd } \\
\text { AND }\end{array}$ & $\mathrm{Dp}$ & Do & & \\
\hline
\end{tabular}

Figure 6 - Matrix representation of the generic model 


\begin{tabular}{|c|c|c|c|c|c|c|c|c|c|c|}
\hline \multicolumn{9}{|c|}{ Attributes } & \multicolumn{2}{|l|}{ Levels } \\
\hline \multicolumn{9}{|c|}{$X_{1}-$ number of pieces of equipment $A$} & \multicolumn{2}{|c|}{$0,1,2,3,4,5$} \\
\hline \multicolumn{9}{|c|}{$X_{2}-$ number of pieces of equipment $B$} & \multicolumn{2}{|c|}{$0,1,2,3,4,5$} \\
\hline \multicolumn{9}{|c|}{$X_{3}-$ number of pieces of equipment $B$} & \multicolumn{2}{|c|}{$0,1,2$} \\
\hline \multicolumn{9}{|c|}{$Y_{11}-$ number of withdrawals per hour on equipment $A$} & \multicolumn{2}{|l|}{$0,1,2,3, \ldots$} \\
\hline \multicolumn{9}{|c|}{$Y_{21}-$ number of on-screen consultations per hour on equipment $A$} & \multicolumn{2}{|c|}{$0,1,2,3, \ldots \ldots 98$} \\
\hline \multirow{2}{*}{\multicolumn{9}{|c|}{$Y_{31}-$ number of printed consultations per hour on equipment $A$}} & \multicolumn{2}{|c|}{$0,1,2,3, \ldots . .50$} \\
\hline & & & & & & & & & \multicolumn{2}{|c|}{$0,1,2,3, \ldots \ldots 57$} \\
\hline \multicolumn{9}{|c|}{$Y_{51}-$ number of payments per hour on equipment $A$} & \multicolumn{2}{|c|}{$0,1,2,3, \ldots \ldots 28$} \\
\hline \multicolumn{9}{|c|}{$Y_{61}-$ number of other transactions per hour on equipment $A$} & \multicolumn{2}{|c|}{$0,1,2,3, \ldots \ldots 39$} \\
\hline \multicolumn{9}{|c|}{$Y_{42-}$ number of deposits per hour on equipment $B$} & \multicolumn{2}{|c|}{$0,1,2,3, \ldots . .30$} \\
\hline \multicolumn{9}{|c|}{$Y_{73}-$ number of 20 -leaf check book per hour on equipment $C$} & \multicolumn{2}{|c|}{$0,1,2,3, \ldots \ldots 24$} \\
\hline \multicolumn{11}{|c|}{ Chromosome } \\
\hline $\mathrm{X}_{1}$ & $\mathrm{X}_{2}$ & $\mathrm{X}_{2}$ & $Y_{11}$ & $\mathrm{Y}_{21}$ & $Y_{31}$ & $\mathrm{Y}_{41}$ & $Y_{51}$ & $Y_{61}$ & $Y_{42}$ & $Y_{73}$ \\
\hline 0 to & 0 to & 0 to & 0 to & 0 to & 0 to & 0 to & 0 to & 0 to & 0 to & 0 to \\
\hline 5 & 5 & 2 & 102 & 98 & 50 & 57 & 28 & 39 & 30 & 24 \\
\hline
\end{tabular}

Figure 7 - Example of the analyzed chromosome

The mathematical representation of the non-linear model is as follows:

$\min Z=\sum_{i=1}^{n} \sum_{j=1}^{m} y_{i j} C V_{i j}+\sum_{j=1}^{m} x_{j} C F_{j}$

subject to:

$\sum_{i=1}^{n} \sum_{j=1}^{m} y_{i j}=D_{i}$

(9) (meeting demand)

$\sum_{j=1}^{m} x_{j} \leq L$

(10) (physical capacity of the location)

$\sum_{i=1}^{n} \sum_{j=1}^{m} y_{i j} t_{i j}=H$

(11) (hourly availability)

$W_{q}=\frac{\mu(\rho)_{j=1}^{\sum_{j j} x_{j}}}{\left(\sum_{j=1}^{m} x_{j}-1\right) !\left(\sum_{j=1}^{m} x_{j} \mu-\lambda\right)^{2}} \times \frac{1}{\left[\sum_{n=0}^{c-1} \frac{1}{n !}(\rho)^{n}\right]+\frac{1}{c !}(\rho)^{n} \frac{c \mu}{c \mu-\lambda}}$

(12) (time in line, equation 6)

$y_{i j}, x_{j} \geq 0$ and integer

With:

$y_{i j}=$ number of transactions $i$ on equipment $j$ 
$x_{j}=$ number of pieces of equipment of type $j$

$C V_{i j}=$ variable cost of transaction $i$ on equipment $j$ (Section 3.3)

$C F_{j}=$ fixed cost of equipment $j$ (Section 3.3)

$t_{i j}=$ average unit time of occupancy of transaction $i$ on equipment $j$

$W_{q}=$ time in line (equation 6 )

$D_{i}=$ demand for transaction $i$ (Table 4)

$L=$ physical capacity for attending in the location in number of people (Table 5)

$H=$ hourly availability for attending (peak demand $=60 \mathrm{~min}$ )

$\lambda=$ rate of customer arrival (Table 4)

$\mu=$ rate of service (Table 2 )

$c=$ number of servers

$\rho=\lambda / \mu$

$p_{0}=$ probability of 0 users on the system (equation 4 )

$m=$ number of different types of equipment (Table 2)

$n=\quad$ number of services offered (Table 2 and 3 )

By analogy, the mathematical representation of the equivalent linear model is as follows:

$\min Z=\sum_{i=1}^{n} \sum_{j=1}^{m} y_{i j} C V_{i j}+\sum_{j=1}^{m} x_{j} C F_{j}$

subject to:

$\sum_{i=1}^{n} \sum_{j=1}^{m} y_{i j}=D_{i}$

(14) (meeting demand)

$\sum_{j=1}^{m} x_{j} \leq L$

(15) (physical capacity of the location)

$\sum_{i=1}^{n} \sum_{j=1}^{m} y_{i j} t_{i j}=H$

(16) (hourly availability)

$y_{i j}, x_{j} \geq 0$ and integer

5. RESULTS

The objective is to find the best mix that meets the demand in accordance with the criterion of time in line at the lowest overall cost. Although there is no specific legislation dealing with time taken using ATM services, current legislation for human cash points was adopted, using an average time of 15 minutes. Due to its special nature and low demand, the service of printing checks was removed from the study 
without affecting the analysis. Brazilian banks usually separate this type of equipment from the rest.

After successive attempts a convergence of results with the following parameter configuration was obtained for the Evolver search tool: (i) $\mathrm{M}=17$ (size of the chromosome); (ii) uniform rate of crossover equal to $50 \%$; (iii) mutation rate of $10 \%$; (iv) stop criterion after 25.000 iterations, and (v) internal Evolver ${ }^{\circledR}$ recipe method. Table 5 summarizes the results obtained using non-linear and linear models. The current situation and the results obtained by the BEP are also presented.

\begin{tabular}{|c|c|c|c|c|c|c|c|c|c|}
\hline \multirow[b]{2}{*}{ Parameter } & \multicolumn{3}{|c|}{ Current Situation } & \multicolumn{2}{|c|}{ GA Model } & \multicolumn{2}{|c|}{ LP Model } & \multicolumn{2}{|c|}{ BEP Model } \\
\hline & & High & Low & High & Low & High & Low & High & Low \\
\hline Equipment A & & 5 & 2 & 5 & 3 & 2 & 2 & 1 & 1 \\
\hline Equipment B & & 4 & 0 & 5 & 0 & 1 & 0 & 1 & 0 \\
\hline Time in line $(\min )^{1}$ & & 3 & $\mathrm{UN}^{3}$ & 3 & 4 & 14 & 12 & 40 & 90 \\
\hline Queue Size (people) $^{2}$ & 7 & 12 & $\mathrm{UN}^{3}$ & 19 & 7 & 36 & 17 & 69 & 72 \\
\hline Total of Equipments & & 9 & 2 & 10 & 3 & 3 & 2 & 2 & 1 \\
\hline
\end{tabular}

Table 5 - Best results

Source: prepared by the author

1 maximum allowed time of 15 minutes (same as minimum at human cash points)

2 maximum line size for High and Low Demand, of 20 and 7 people, respectively.

3 Unknown

The LP model gives the lowest cost but requires a lot of waiting time from customers. However, the results show that LP can be an efficient and practical model for low demand branches. It may be implemented using popular software such as Solver from Microsoft Excel ${ }^{\circledR}$. Low demand branches represent a relevant category in the banking system comprising hundreds or even thousands of branches.

According to Brazilian legislation, banks must publish their transaction fees in their branches and on the Internet. In order to obtain the results, the average transaction fee for the studied bank was used as the average selling price. As stated in section 1, the BEP model is essentially a cost optimization method that does not consider capacity or quality restrictions. As expected, it presented lower numbers and worse performance than other methods.

The GA model provided more realistic results when compared with the current situation. Moreover, the GA model recommends more specialist machines in high demand environments. According to the $\mathrm{M} / \mathrm{M} / \mathrm{c}$ queuing model, this an expected result because of the difference between service rates. The fact of the suggested equipment configuration is close, but not equal, to the current situation is a coincidence caused by the branches imposed by the studied bank.

Table 6 compares the performance of two pieces of equipment: multifunctional $A$ (withdrawal, consultation, deposit, payment) and specialist $B$ (deposit, consultation). The parameters of queuing theory $L q$ and $W q$ were used to compare the performance of two pieces of equipment $A$ and $B$ while using common transaction deposit at peak demand. As expected, Machine $A$ presents worse results, in other words, more $A$ machines rather than $B$ are necessary for the same customer's arrival rate. This result 
is in line with Abensur et al. (2003), who tested different configurations of ATMs for similar branches and proved that a multifunctional strategy needs more machines than a specialist strategy.

\begin{tabular}{|c|c|c|c|c|c|c|}
\cline { 2 - 7 } \multicolumn{1}{c|}{} & \multicolumn{2}{|c|}{ Machine A (2) } & \multicolumn{2}{c|}{ Machine B (2) } & \multicolumn{2}{c|}{$(\mathrm{A} / \mathrm{B})$} \\
\hline$\lambda(\mathrm{cls} / \mathrm{h})$ & $L q(\mathrm{cls})$ & $W q(\mathrm{~min})$ & $L q$ & $W q$ & $L q$ & $W q$ \\
\hline 30 & 0.0400 & 0.0013 & 0.0216 & 0.0007 & 1.85 & 1.85 \\
50 & 0.2141 & 0.2570 & 0.1097 & 0.1320 & 1.95 & 1.95 \\
60 & 0.4141 & 0.4140 & 0.2030 & 0.2030 & 2.04 & 2.04 \\
100 & 6.2738 & 3.7640 & 1.6067 & 0.9640 & 3.90 & 3.90 \\
120 & - & - & 5.4175 & 2.7090 & - & - \\
\hline
\end{tabular}

Table $6-\mathrm{M} / \mathrm{M} / \mathrm{c}$ queuing model comparison $\left(\mu_{A}=1.06 \mathrm{~min} ; \mu_{B}=0.87 \mathrm{~min}\right)$ Source: Prepared by the author

ATMs are worldwide pieces of equipment that offer similar transactions. In the Brazilian banking market there are few ATM suppliers that have the capacity of delivering high level service for equipment similar to that shown in Table 7 below. As stated in section 3, the particular branch was chosen because it has a public that is both diversified and representative of the Brazilian banking customer population (gender, age, income, education, electronic banking skills, physical disabilities). The aforementioned reasons suggest that the proposed methodology and results can be applied to other branches and banks.

\begin{tabular}{lcccc}
\hline Transaction & $\begin{array}{c}\text { Case } \\
\text { Study } \\
\text { Machine }\end{array}$ & $\begin{array}{c}\text { Bank 1 } \\
\text { Machine C }\end{array}$ & $\begin{array}{c}\text { Bank 2 } \\
\text { Machine D }\end{array}$ & $\begin{array}{c}\text { Bank 3 } \\
\text { Machine E }\end{array}$ \\
\hline Withdrawal & A & & & \\
$\begin{array}{l}\text { On-screen } \\
\text { consultation }\end{array}$ & $\bullet$ & $\bullet$ & $\bullet$ & $\bullet$ \\
$\begin{array}{l}\text { Printed consultation } \\
\text { Deposit }\end{array}$ & $\bullet$ & $\bullet$ & $\bullet$ & $\bullet$ \\
Payment & $\bullet$ & $\bullet$ & $\bullet$ & 0 \\
\hline
\end{tabular}

Table 7 - Comparison of the ATM services of similar pieces of equipment Source: Prepared by the author

- Available

O Not available

\section{CONCLUSIONS}

This work has integrated the concepts of Queuing Theory with the search potential of Genetic Algorithms and presents a more realistic approach to the subject 
as applied to the management of ATMs. The study considered relevant aspects of the daily banking reality such as cost restrictions, space, user skill, equipment diversity and time in line.

The GA model gives results that are close to the corporate reality. As expected, the inclusion of line restrictions increased the demand for equipment in comparison to what is currently available, which is based on non-objective criteria. This recommendation is based on a time-in-line criterion adapted from the legislation that deals with human cash points, but there is a need for studies that are more appropriate to ATM lines, which offer fewer, more standardized services than those offered by the human cash point. Such studies would probably indicate that with the increase in the number of pieces of equipment suggested the time in line at ATMs would be less than those that were used. The results are in line with the complaints of Brazilian users (BACEN, 2010) that generally consider that the banking resources allocated are insufficient for providing service. Although the LP model gives a guarantee of an optimum solution (less equipment and lower costs), it violates the restriction of time in line and therefore service quality. The difference between the number of pieces of equipment suggested and the current situation is even more significant in high demand conditions. However, the LP model proved to be a practical and interesting alternative for low demand branches.

The results point to the recommendation of specialist equipment (one or few functions) in high demand situations and multifunctional equipment (several functions) in low demand situations. Another possibility would be the use of multifunctional equipment to complement specialist machinery.

The method required a survey of hourly demand in the location studied and measurement of occupancy times; that might be operationally limiting in other applications. However, the current IT resources of Brazilian banks allow for large volumes of data to be handled and consolidated and time measurements are already normally carried out. Defining the mix of ATMs at peak demand requires more investment from banks but is an acceptable sacrifice given the costs of losing customers.

A method for determining electronic banking resources was developed that balances conditions that are of interest to the service provider (number and diversity of equipment, costs, physical space) with restrictions that are of interest to the user (time in line). This study may encourage other works in order to determine other metaheuristic approaches applied to the ATM problem.

\section{REFERENCES}

ABENSUR, E. O.; FISCHMANN, A. A.; BRUNSTEIN, I.; HO, L. L. Tendências para o Auto-Atendimento Bancário Brasileiro: um Enfoque Estratégico baseado na Teoria das Filas. Revista de Administração Mackenzie, v.4, n.2, p. 39-59, 2003. 
ATKINSON, J. B.; KOVALENKO, I. N.; KUZNETSOV, N.; MYKHALEVYCH, K. V. A Hypercube queueing loss model with customer-dependent service rates. European Journal of Operational Research, vol.191, n.1, p.221-237, 2008.

BACEN. Atendimento ao Público. Disponível em http://www.bacen.gov.br. Acesso em 03. out.2010.

BALAKRISHNAN, P. V.; JACOB, V. S. Genetic Algorithms for Product Design. Management Science, v.42, n.8, p.1105-1117, 1996.

BERMAN, O.; DREZNER, Z. The Multiple Server Location Problem. Journal of the Operational Research Society, v.58, p.91-99, 2007.

CASTRO, J. A Stochastic Programming Approach to Cash Management in Banking. European Journal of Operational Research, v.192, n.3, p.963-974, 2009.

FEBRABAN. Dados do Setor. Disponível em http://www.febraban.org.br. Acesso em 24.nov. 2010.

HEIZER, J., RENDER, B. Operations Management. New Jersey: Prentice Hall, 1999. $647 p$.

HILLIER, F. S.; LIEBERMAN, G. J. Introdução à Pesquisa Operacional. São Paulo: EDUSP, 1988. 998p.

HOLLAND, J. H. Adaptation in Natural and Artificial Systems. Ann Arbor: The University of Michigan Press, 1975. 211p.

KOUZELIS, A. On the Determinants of ATM Performance. European Journal of Operational Research, v.30, n.1, p.89-94, 1987.

LAMY, R. Custo de produtos e serviços bancários. IBCB, São Paulo. 1987. 147p.

LARSON, R.; FARBER, B. Elementary Statistics. New Jersey: Prentice Hall, 2004. 476p.

MURPHY, N. Determinants of ATM Activity: The Impact of Card Base, Location, Time in Place and System. Journal of Banking Research, v.14, p.231-233, 1983.

SYAM, S. S. A Multiple Server Location-Allocation Model for Service System Design. Computers \& Operations Research, v.35, n.7, p.2248-2265, 2008.

TAHA, H. A. Operations Research: an Introduction. New Jersey: Prentice Hall, 2008. $359 p$.

THATCHER, A.; SHAIK, F.; ZIMMERMAN, C. Attitudes of semi-Literate and Literate Bank Account Holders to the Use of Automatic Teller Machines. International Journal of Industrial Ergonomics, v.35, n.2, p.115-130, 2005. 